\title{
Germination Impact in the Nutrition and Technological Properties of Jackfruit Seeds
}

\author{
Daniela Dantas de Farias Leite (Corresponding Author), Alexandre José de Melo Queiroz, \\ Rossana Maria Feitosa de Figueirêdo, Ana Regina Nascimento Campos, Dyego da Costa \\ Santos, Thalis Leandro Bezerra de Lima \\ Universidade Federal de Campina Grande, Brazil
}

Received: Sep. 28, 2019

doi:10.5296/jas.v8i1.15524
Accepted: Oct. 16, $2019 \quad$ Published: Oct. 21, 2019

URL: https://doi.org/10.5296/jas.v8i1.15524

\begin{abstract}
The objective of this study was the production of flour from germinated jackfruit seeds. The seeds were germinated and dried at temperatures of 55,65 and $75{ }^{\circ} \mathrm{C}$ under air drying speed of 1.0 and $1.3 \mathrm{~m} \mathrm{~s}^{-1}$. Afterward, the seeds were grounded in order to obtain the flour and characterized for chemical, physical and technological properties. It was observed that the germination increased the moisture content, proteins, and fibers; decreased the content of lipids, reducing sugars, tannins and phenolic compounds of the seeds. After dried, the flour moisture content decreased and the proteins and reducing sugars were concentrated. The flours showed good results for solubility, water, oil absorption capacity, and emulsifying properties. The moisture adsorption isotherms of the flours were classified as Type II and the GAB model was the best fit to the experimental data.
\end{abstract}

Keywords: Artocarpus heterophyllus Lam., agroindustrial residues, germination process, drying

\section{Introduction}

Jackfruit (Artocarpus heterophyllus Lam.) is a tropical fruit widely consumed in countries such as Thailand, Indonesia, India, Philippines, Malaysia and Brazil (Madrigal-Aldana et al., 2011). The edible part of this fruit can be considered a good source of essential nutrients such as proteins, calcium, and iron when compared to other tropical fruits (Baliga et al., 2011). The pulp, although consumed in natura, can be used in the production of jams, jellies, ice cream, juices, and the seeds can be consumed roasted or cooked (Madruga et al., 2014). The seeds contain high quantities of carbohydrates and proteins and their flour has been investigated for application in bakery products (Madrigal-Aldana et al., 2011).

The germination process has been used to improve the nutritional quality of several seeds. In addition, it is a low-cost technology that provides better absorption of nutrients associated 
with biologically active compounds with antioxidant potential (Cornejo et al., 2015). During germination, the enzymatic activity promotes the hydrolysis of the starch into simple sugars and other changes in the nutritional components (Charoenthaikij et al., 2012).

After the germination process, which starts after hydration, the seed presents high moisture content. To avoid deterioration, the material must be dried as soon as possible. After dried, the seeds can be kept on hold for further processing steps and be stored in environmental conditions that may include transformation into flours.

Drying time combinations and temperatures directly affect the properties and nutritional composition, therefore, the analysis of the relations between the process conditions and these properties needs to be performed. Knowledge of the functional and technological properties of food is essential for the food industry since it is the physical and chemical aspects that reflect the characteristics desired by consumers (Naves et al., 2010). The moisture content, depending on the material and environmental conditions, significantly influence the characteristics of the product, in content and shape, for this reason, drying behavior and hygroscopicity needs to be determined individually for different materials.

Although used in the culinary, there are no studies available on the use of jackfruit flour and the use of germinated seed, thus there is a demand for studies that characterize its technological aspects, in addition to its applications in other products. Therefore, this work aimed to produce and evaluate the characteristics and hygroscopic properties of germinated jackfruit seeds flour.

\section{Material and Method}

\subsection{Raw-material}

Jackfruit seeds (Artocarpus heterophyllus Lam.) of the soft pulp variety were used as raw material. The seeds were extracted, sanitized with $1 \%$ sodium hypochlorite solution, washed and placed on a bench to dry, for approximately $2 \mathrm{~h}$.

\subsection{Seed Germination}

The seeds were placed in plastic trays, containing vermiculite as substrate $(700 \mathrm{~g})$, and irrigated with $400 \mathrm{~mL}$ of distilled water each tray, every 2 days. After 15 days of germination, the radicle was obtained with the desired length of $2.5 \mathrm{~cm}$ (Silva et al., 2007).

\subsection{Physico-chemical Characterization}

Water activity $\left(\mathrm{a}_{\mathrm{w}}\right)$ was determined in triplicate using Aqualab model 3TE equipment (Decagon Devices, Inc.); the moisture content, ash, total titratable acidity, $\mathrm{pH}$ and protein content were determined according to the analytical procedures of the Instituto Adolfo Lutz (IAL, 2008); the lipids content was determined by the methodology of Bligh and Dyer (1959); ascorbic acid was determined following AOAC procedures (2009); the total carbohydrates was calculated by the difference between the initial percentage of the sample (100\%) and the percentage of moisture, protein, lipids, ashes and fiber content.

The total sugars quantification was performed using the methodology proposed by Yemm and 
Willis (1954); the reducing sugar content was determined following the procedure proposed by Miller (1959) and starch by the anthrone method (Stevens and Chapman, 1955). The tannins were analyzed according to the methodology described by Goldstein and Swain (1963). The total phenolic compounds content was determined by the Folin-Ciocalteau spectrophotometric method, according to the methodology proposed by Waterhouse (2006), with modifications.

The determination of neutral detergent fiber content was performed as described by Souza (1999). The color parameters of the samples were determined with the MiniScan HunterLab XE Plus spectrophotometer in the CieLab color system $\left(\mathrm{L}^{*}, \mathrm{a}^{*}\right.$, and $\left.\mathrm{b}^{*}\right)$, where $\mathrm{L}^{*}$ is the luminosity, $a^{*}$ is the transition from green color $\left(-a^{*}\right)$ for the red color $\left(+a^{*}\right)$ and $b^{*}$ the transition from the blue color $\left(-b^{*}\right)$ to the yellowness $\left(+b^{*}\right)$.

The bulk density was determined by immersion of individual seeds into a beaker filled with distilled water, in an analytical scale. The seeds were fixed with an entomological pin attached to a mobile support until completely immersed, but as close as possible to the surface, the relation between the seed mass and its unit volume was determined, the unit mass corresponded to the volume of water displaced. It was considered for distilled water $1 \mathrm{~L}=1$ $\mathrm{cm}^{3}$, and for the unit masses, the individual weight of the seeds. The bulk density was determined by the mass/volume ratio of the samples using a $600 \mathrm{~mL}$ beaker filled with seeds.

The minerals determination was carried out in an X-ray fluorescence spectrometer by Shimadzu, model EDX-720.

\subsection{Convective Drying}

The germinated (whole) seeds of jackfruit were dried in six different temperatures and air velocity, they were dehydrated to a moisture content of approximately $9.5 \%$, in order to inhibit the development of microorganisms and biochemical reactions. To obtain the flour, dehydrated jackfruit seeds were ground in a knife mill and received the following codes: $\mathrm{F} 1$ $\left(55^{\circ} \mathrm{C}\right.$ and $1.0 \mathrm{~m} \mathrm{~s}^{-1}$ air velocity); F2 (55 ${ }^{\circ} \mathrm{C}$ and $1.3 \mathrm{~m} \mathrm{~s}^{-1}$ air velocity); F3 (65 ${ }^{\circ} \mathrm{C}$ and $1.0 \mathrm{~m}$ $\mathrm{s}^{-1}$ air velocity); F4 (65 ${ }^{\circ} \mathrm{C}$ and $1.3 \mathrm{~m} \mathrm{~s}^{-1}$ air velocity); F5 $\left(75{ }^{\circ} \mathrm{C}\right.$ and $1.0 \mathrm{~m} \mathrm{~s}^{-1}$ air velocity) and F6 ( $75^{\circ} \mathrm{C}$ and $13, \mathrm{~m} \mathrm{~s}^{-1}$ air velocity).

\subsection{Flour Characterization}

Flours of the germinated jackfruit seeds were characterized for the chemical and physical parameters described above, bulk density, tapped density and particle density. For the bulk density, a mass of known flour was used and transferred to a graduated cylinder in which the volume was used to calculate the bulk density by the ratio of mass to volume. For the determination of the tapped density, the methodology of Tonon et al. (2013) was used. The particle density was determined by the pycnometric method, toluene was used as an immiscible liquid, at $25^{\circ} \mathrm{C}$.

The Hausner factor was calculated by the ratio between the tapped density and the bulk density. The Carr index was calculated according to Bhusari et al. (2014).

Solubility was determined by the method of Eastman and Moore (1984) modified by 


\section{Macrothink}

Journal of Agricultural Studies

ISSN 2166-0379

2020, Vol. 8, No. 1

Cano-Chauca et al. (2005). The method of Beuchat (1977) was used with adaptations for the determination of water and oil absorption capacity. The method of Yasumatsu et al. (1972), with adaptations, was used to determine emulsions activity and stability. The results for emulsion activity (EA) were expressed as percentage of emulsion formed in the total volume. Emulsion stability (ES) was measured by centrifugation of the samples after heating the emulsion in a water bath at $80{ }^{\circ} \mathrm{C}$ for $30 \mathrm{~min}$ and cooling to room temperature. The height of the emulsified layer, as a percentage of the total height of the material, was used to calculate the emulsion stability.

\subsection{Moisture Adsorption Isotherms of Flour}

The moisture adsorption isotherms of the jackfruit seed flour germinated at $25{ }^{\circ} \mathrm{C}$ were determined according to the special static indirect method proposed by Crapiste and Rotstein (1982). To measure the water activity, the Hygrometer Aqualab model 3 TE, Decagon Devices was used.

On Table 1 are presented the Oswin, Peleg and GAB models that were fitted to the moisture adsorption isotherms using non-linear regression. The Quasi-Newton method was used in the statistics 7.7 software.

Table 1. Mathematical models for adjustment of moisture adsorption isotherms

\begin{tabular}{|c|c|c|}
\hline Designed models & Equation & \\
\hline Oswin & $\mathrm{x}_{\mathrm{e}}=\mathrm{a}\left(\frac{\mathrm{a}_{\mathrm{w}}}{1-\mathrm{a}_{\mathrm{w}}}\right)^{\mathrm{b}}$ & (1) \\
\hline Peleg & $\mathrm{X}_{\mathrm{e}}=\mathrm{k}_{1} \mathrm{a}_{\mathrm{ww}}{ }^{\mathrm{n} 1}+\mathrm{k}_{2} \mathrm{a}_{\mathrm{w}}{ }^{\mathrm{n} 2}$ & (2) \\
\hline $\begin{array}{l}\text { GAB (Gugghenheim, Anderson } \\
\text { Boer) }\end{array}$ & $\mathrm{X}_{\mathrm{e}}=\left(\frac{\mathrm{X}_{\mathrm{m}} \cdot \mathrm{C} \cdot \mathrm{K} \cdot \mathrm{a}_{\mathrm{ww}}}{\left(1-\mathrm{K} \cdot \mathrm{a}_{\mathrm{w}}\right) \cdot\left(1-\mathrm{K} \cdot \mathrm{a}_{\mathrm{w}}+\mathrm{C} \cdot \mathrm{K} \cdot \mathrm{a}_{\mathrm{w}}\right)}\right)$ & (3) \\
\hline
\end{tabular}

Where: $X_{e}-$ Equilibrium moisture content, $\mathrm{kg} / \mathrm{kg} ; \mathrm{X}_{\mathrm{m}}-$ moisture content in the molecular monolayer, $\mathrm{kg} / \mathrm{kg} ; \mathrm{a}_{\mathrm{w}}$ - water activity, dimensionless; $\mathrm{T}$ - temperature $\left({ }^{\circ} \mathrm{C}\right) ; \mathrm{a}, \mathrm{b}, \mathrm{c}, \mathrm{k}, \mathrm{k}_{1}, \mathrm{k}_{2}$, $\mathrm{n}_{1}, \mathrm{n}_{2}-$ equation constants.

The criteria used to determine the best fit of the models to the experimental data were the coefficient of determination $\left(\mathrm{R}^{2}\right)$ and the mean percentage deviation $(\mathrm{P})$, calculated according to Equation 4.

$$
P=(100 / n) \cdot \sum_{i=1}^{n}\left(X_{\exp }-X_{p r e}\right) / X_{\exp }
$$




\section{Macrothink}

Where: $\mathrm{P}$ - average deviation percentage $(\%) ; \mathrm{X}_{\exp }$ - values obtained experimentally; $\mathrm{X}_{\text {pre }}$ values predicted by the model; $\mathrm{n}$ - number of experimental data.

\subsection{Flour Particles Morphology}

An X-ray diffraction pattern equipment model Shimadzu XRD-6000 with CuK $\alpha$ radiation, 40 $\mathrm{kV}, 30 \mathrm{~mA}$ current, step size of $0.0202 \theta$ and time per step of $1,000 \mathrm{~s}$, the speed of scan of $2^{\circ}$ $(2 \theta) / \mathrm{min}$, with angle $2 \theta$ traversed from 4 to $50^{\circ}$. The particle morphology was detailed using SSX-550 Superscan Scanning Electron Microscope (SEM) from Shimadzu, Japan, operated at $15 \mathrm{kV}$. To obtain the images, the sample was metalized with a gold alloy and fixed in the sample port with carbon fiber. The metallization was carried out for 3 min under high vacuum, with a $10 \mathrm{~mA}$ current. The images were collected with magnification from 500 to 2000x.

\subsection{Data Analysis}

The data obtained from the chemical, physical and technological characterization were submitted to analysis of variance and the comparison between means by the Tukey test at $5 \%$ of probability. The software Assistat, version 7.7 beta (Silva and Azevedo, 2016) was used.

\section{Results and Discussion}

\subsection{Characterization of the in Nature and Germinated Jackfruit Seeds}

Table 2 shows the average results for the chemical, physical and mineral characterization of the in nature and germinated jackfruit seeds. 
Table 2. Chemical, physical and mineral profile characterization of the in nature and germinated jackfruit seeds

\begin{tabular}{|c|c|c|}
\hline \multirow{2}{*}{ Parameter } & \multicolumn{2}{|c|}{ Jackfruit seed } \\
\hline & In natura (b.s.) & Germinated (b.s.) \\
\hline Water activity $\left(\mathrm{a}_{\mathrm{w}}\right)$ at $25{ }^{\circ} \mathrm{C}$ & $0.983 \pm 0.001 b$ & $0.989 \pm 0.001 \mathrm{a}$ \\
\hline Moisture content $(\%)$ & $49.69 \pm 0.25 b$ & $57.04 \pm 0.79 \mathrm{a}$ \\
\hline Ashes (\%) & $2.60 \pm 0.02 \mathrm{a}$ & $2.14 \pm 0.04 \mathrm{~b}$ \\
\hline Titratable total acidity $(\%)$ & $0.89 \pm 0.00 \mathrm{~b}$ & $1.21 \pm 0.04 \mathrm{a}$ \\
\hline $\mathrm{pH}$ & $5.71 \pm 0.01 \mathrm{a}$ & $5.54 \pm 0.05 b$ \\
\hline Proteins $(\%)$ & $8.90 \pm 0.10 b$ & $11.95 \pm 0.07 \mathrm{a}$ \\
\hline Lipids (\%) & $27.81 \pm 0.81 \mathrm{a}$ & $15.38 \pm 0.04 b$ \\
\hline Ascorbic acid (mg/100 g) & $31.78 \pm 0.02 \mathrm{a}$ & $10.38 \pm 0.04 b$ \\
\hline Total carbohydrates $(\%)$ & $39.25 \pm 0.34 \mathrm{a}$ & $31.96 \pm 0.09 b$ \\
\hline Total sugars (\% glycose $)$ & $10.48 \pm 0.00 \mathrm{~b}$ & $12.66 \pm 0.01 \mathrm{a}$ \\
\hline Reducing sugars (\% glycose) & $1.85 \pm 0.06 \mathrm{a}$ & $1.66 \pm 0.00 \mathrm{a}$ \\
\hline Starch content $(\%)$ & $22.04 \pm 0.05 \mathrm{a}$ & $14.73 \pm 0.02 b$ \\
\hline Tannins (g/100 g of sample) & $0.23 \pm 0.003 \mathrm{a}$ & $0.17 \pm 0.005 b$ \\
\hline Phenolic compounds (g/100 g of sample) & $0.16 \pm 0.003 \mathrm{a}$ & $0.12 \pm 0.005 \mathrm{~b}$ \\
\hline Neutral detergent fiber $(\%)$ & $18.37 \pm 0.24 b$ & $34.74 \pm 0.24 \mathrm{a}$ \\
\hline Luminosity (L*) & $64.54 \pm 0.11 b$ & $65.24 \pm 0.09 \mathrm{a}$ \\
\hline Redness $\left(+\mathrm{a}^{*}\right)$ & $3.86 \pm 0.08 \mathrm{a}$ & $3.73 \pm 0.06 \mathrm{~b}$ \\
\hline Yellowness $\left(+b^{*}\right)$ & $16.19 \pm 0.20 \mathrm{~b}$ & $16.75 \pm 0.18 \mathrm{a}$ \\
\hline Particle density $\left(\mathrm{g} / \mathrm{cm}^{3}\right)$ & $1.2151 \pm 0.1260 \mathrm{a}$ & $1.1104 \pm 0.0642 \mathrm{~b}$ \\
\hline Volume $\left(\mathrm{cm}^{3}\right)$ & $4.3838 \pm 0.6610 b$ & $5.9216 \pm 1.6844 \mathrm{a}$ \\
\hline Unit mass (g) & $4.9141 \pm 0.8357 \mathrm{~b}$ & $6.6319 \pm 2.1492 \mathrm{a}$ \\
\hline Bulk density $\left(\mathrm{g} / \mathrm{cm}^{3}\right)$ & $0.6373 \pm 0.0114 \mathrm{a}$ & $0.5925 \pm 0.0030 \mathrm{~b}$ \\
\hline Potassium (K) (mg/100 g) & 712.98 & 563.15 \\
\hline Phosphorus (P) (mg/100 g) & 227.71 & 172.45 \\
\hline Magnesium (Mg) (mg/100 g) & 200.24 & 184.22 \\
\hline Sulfur (S) (mg/100 g) & 51.19 & 28.97 \\
\hline Calcium $(\mathrm{Ca})(\mathrm{mg} / 100 \mathrm{~g})$ & 42.99 & 45.58 \\
\hline Zinc $(\mathrm{Zn})(\mathrm{mg} / 100 \mathrm{~g})$ & 0.67 & 0.54 \\
\hline Iron $(\mathrm{Fe})(\mathrm{mg} / 100 \mathrm{~g})$ & 0.59 & 0.62 \\
\hline Cupper $(\mathrm{Cu})(\mathrm{mg} / 100 \mathrm{~g})$ & 0.31 & 0.29 \\
\hline
\end{tabular}

Means followed by the same letter in the rows are not statistically different at $5 \%$ probability, by the Tukey test. Moisture content-dependent values expressed as dry basis (d.b.). 
The water activity showed a small increase after the germination process, this is associated with the watering of the seeds, which induces water absorption. There are no studies in the literature that mention the water activity increase resulted from the seed germination process. The moisture content increased by more than $7 \%$ between in natura seeds and germinated seeds, this corroborates with the detected increase in water activity. Increased moisture content was also verified by Martinez et al. (2011) in samples of germinated soybean when compared to the control, with averages of 63.73 and $6.71 \%$, respectively, and by Leite et al. (2016) for sorghum seeds in natura and germinated, with values of 12.16 and 36\%, respectively.

It was observed a decrease in ash content after the germination process which is probably due to the proportionally larger amount of minerals present in the radicle, discarded after germination. Conversely, there was an increase in titratable total acidity after germination. Leite et al. (2016) also reported an increased acidity in sorghum seeds after the germination process and reported values of $1.08 \mathrm{~g}$ equivalent acid/100 $\mathrm{g}$ (in natura) and $1.99 \mathrm{~g}$ equivalent $\mathrm{acid} / 100 \mathrm{~g}$ (germinated). The decreased value for $\mathrm{pH}$, from 5.71 to 5.54 , between the in natura and germinated seeds, respectively, was expected, an inverse behavior to what was observed for the acidity.

There was an increase of more than $34 \%$, in absolute values, for protein content in the germinated seeds in relation to the in natura seeds. Martinez et al. (2011) also observed an increase in protein content, from 35.67 to $42.02 \%$ (17.6\% in absolute values) in control and germinated soybeans, respectively. For the lipid content, a statistical difference was observed between the samples, after the germination process, where the lipid content decreased to just over half the content of the sample in natura.

The ascorbic acid content decreased significantly after the germination process. Huang et al. (2014) also observed an increase in ascorbic acid content in mung bean (Vigna radiata L.) and soybean germinated for 3 days, followed by a decrease when reached the fifth day of germination, this indicates that the ascorbic acid content in germinated seeds depends on the transcurred period from the germination start. The carbohydrates content, obtained by difference, presented a decrease of $18.6 \%$ in germinated seeds. Similar results were found by Martinez et al. (2011) in soybean seeds, where the carbohydrate content decreased from 21.11 (in natura) to $9.81 \%$ after germination.

After the germination process, the total sugar content increased and the reducing sugars decreased. The increase in total sugars is probably due to the activity of $\alpha$-amylase, resulted from the formation of simple sugars, which also explains the values obtained for the starch content, where a decrease in the germinated samples was observed. Tian et al. (2010) also observed a decrease in the starch content after germination in oat seeds and obtained values of $59.80 \%$ in the in natura seeds and $52.89 \%$ in the seeds with $24 \mathrm{~h}$ of germination. It was observed a significant decrease of the tannin content in the seeds after germination, which can be attributed to the oxidation of polyphenols, which is activated during germination and causes tannins enzymatic hydrolysis.

It was observed a decrease in the phenolic compounds content after germination, which 
corroborates that the germinative process decreases the antinutritional factors, consequently increasing the bioavailability of the nutrients. The neutral detergent insoluble fiber (NDF) content showed a significant increase after the germination process.

The germination process caused significant changes in the color parameters, but not expressive, with increases in luminosity $\left(\mathrm{L}^{*}\right)$, justified by the reduction of tannin content, also for yellowness $\left(+b^{*}\right)$, and decrease in redness $\left(+a^{*}\right)$.

Germination reduced the absolute and bulk density, which is justified by the increase of moisture content incorporated in the samples. The unit mass and volume increased, both 35\%, indicating a similar influence of moisture absorption on the volume and the size of the seeds. Devilla et al. (2010) studied the physical properties of common bean seeds (Phaseolus vulgaris L.) and found a unit mass value of 1.254 to $1.295 \mathrm{~g}$ for a moisture content range between 22.8 and $11 \%$, a quadratic increase of the unit mass with the decrease of the moisture content was observed, with determination coefficients of 0.039 and 0.023 . The authors related this difference to variations in seed size and shape.

There was a decrease for most minerals, such as potassium, phosphorus, and magnesium after the germination process. The microminerals zinc, sulfur, and copper also decreased. The decrease of these minerals may have occurred by water leaching from the irrigation used in the germination process or were eliminated in the discarded roots. The content of iron and calcium increased with the germination process, which is probably due to their absorption from the substrate.

\subsection{Characterization of Germinated Jackfruit Seeds Flour}

Table 3 shows the mean values of water activity, moisture content, protein, lipids, starch, crude fiber, redness, yellowness, luminosity, bulk density, tapped density, particle density, Hausner and Carr index of germinated jackfruit seed flour, dried at 55,65 and $75{ }^{\circ} \mathrm{C}$ and air velocities of 1.0 and $1.3 \mathrm{~m} \mathrm{~s}^{-1}$. 
Table 3. Average values of the germinated jackfruit seed flour obtained at different drying temperatures and air velocities.

\begin{tabular}{|c|c|c|c|}
\hline & \multirow{2}{*}{$\begin{array}{c}\text { Temperature } \\
\left({ }^{\circ} \mathbf{C}\right)\end{array}$} & \multicolumn{2}{|c|}{ Air velocity $\left(\mathrm{m} \mathrm{s}^{-1}\right)$} \\
\hline & & 1.0 & 1.3 \\
\hline \multirow{3}{*}{ Water activity } & 55 & $0.410 \mathrm{cA}$ & $0.407 \mathrm{bB}$ \\
\hline & 65 & $0.446 \mathrm{aA}$ & $0.419 \mathrm{aB}$ \\
\hline & 75 & $0.414 \mathrm{bA}$ & $0.406 \mathrm{bB}$ \\
\hline \multirow{3}{*}{ Moisture content (\%) } & 55 & $9.48 \mathrm{aA}$ & $9.26 \mathrm{aA}$ \\
\hline & 65 & $9.39 \mathrm{aA}$ & $9.30 \mathrm{aA}$ \\
\hline & 75 & $9.47 \mathrm{aA}$ & $9.31 \mathrm{aA}$ \\
\hline \multirow{3}{*}{ Proteins (\%) } & 55 & $11.92 \mathrm{bA}$ & $12.24 \mathrm{aA}$ \\
\hline & 65 & $11.06 \mathrm{cA}$ & $11.22 \mathrm{bA}$ \\
\hline & 75 & $13.97 \mathrm{aA}$ & $11.42 \mathrm{bB}$ \\
\hline \multirow{3}{*}{ Lipids (\%) } & 55 & $0.073 \mathrm{aA}$ & $0.069 \mathrm{aA}$ \\
\hline & 65 & $0.080 \mathrm{aA}$ & $0.072 \mathrm{aA}$ \\
\hline & 75 & $0.073 \mathrm{aA}$ & $0.069 \mathrm{aA}$ \\
\hline \multirow{3}{*}{ Starch $(\%)$} & 55 & $30.81 \mathrm{cA}$ & $31.87 \mathrm{cA}$ \\
\hline & 65 & $32.43 \mathrm{bB}$ & $33.86 \mathrm{bA}$ \\
\hline & 75 & $35.10 \mathrm{aB}$ & $37.20 \mathrm{aA}$ \\
\hline \multirow{3}{*}{ Crude Fiber (\%) } & 55 & $8.24 \mathrm{aA}$ & $7.69 \mathrm{aA}$ \\
\hline & 65 & $5.19 \mathrm{bB}$ & $7.44 \mathrm{aA}$ \\
\hline & 75 & $5.12 \mathrm{bA}$ & $5.23 \mathrm{bA}$ \\
\hline \multirow{3}{*}{ Redness $\left(+a^{*}\right)$} & 55 & $3.20 \mathrm{aA}$ & $2.71 \mathrm{aB}$ \\
\hline & 65 & $2.18 \mathrm{bA}$ & $2.25 \mathrm{bA}$ \\
\hline & 75 & $2.07 \mathrm{bB}$ & $2.81 \mathrm{aA}$ \\
\hline \multirow{3}{*}{ Yellowness $\left(+b^{*}\right)$} & 55 & $18.32 \mathrm{aA}$ & $17.37 \mathrm{bB}$ \\
\hline & 65 & $16.25 \mathrm{bA}$ & $14.39 \mathrm{cB}$ \\
\hline & 75 & $14.82 \mathrm{cB}$ & $18.95 \mathrm{aA}$ \\
\hline \multirow{3}{*}{ Luminosity $\left(\mathrm{L}^{*}\right)$} & 55 & $71.78 \mathrm{cB}$ & $72.88 \mathrm{cA}$ \\
\hline & 65 & $75.12 \mathrm{bA}$ & $75.30 \mathrm{aA}$ \\
\hline & 75 & $76.20 \mathrm{aA}$ & $73.80 \mathrm{bB}$ \\
\hline \multirow{3}{*}{ Bulk density $\left(\mathrm{g} / \mathrm{cm}^{3}\right)$} & 55 & $0.6367 \mathrm{aA}$ & $0.5967 \mathrm{aA}$ \\
\hline & 65 & $0.5800 \mathrm{aA}$ & $0.5000 \mathrm{bB}$ \\
\hline & 75 & $0.4767 \mathrm{bB}$ & $0.5400 \mathrm{abA}$ \\
\hline \multirow{3}{*}{$\begin{array}{l}\text { Tapped density } \\
\left(\mathrm{g} / \mathrm{cm}^{3}\right)\end{array}$} & 55 & $0.6667 \mathrm{aA}$ & $0.6233 \mathrm{aA}$ \\
\hline & 65 & $0.6067 \mathrm{aA}$ & $0.5233 \mathrm{bB}$ \\
\hline & 75 & $0.5000 \mathrm{bA}$ & $0.5467 \mathrm{abA}$ \\
\hline \multirow{3}{*}{$\begin{array}{l}\text { Particle density } \\
\qquad\left(\mathrm{g} / \mathrm{cm}^{3}\right)\end{array}$} & 55 & $1.5967 \mathrm{aA}$ & $1.3100 \mathrm{abB}$ \\
\hline & 65 & $1.5533 \mathrm{aA}$ & $1.3233 \mathrm{aB}$ \\
\hline & 75 & $1.4367 \mathrm{bA}$ & $1.2400 \mathrm{bB}$ \\
\hline \multirow{3}{*}{ Fator de Hausner } & 55 & $1.049 \mathrm{aA}$ & $1.048 \mathrm{aA}$ \\
\hline & 65 & $1.047 \mathrm{aA}$ & $1.050 \mathrm{aA}$ \\
\hline & 75 & $1.045 \mathrm{aA}$ & $1.018 \mathrm{aA}$ \\
\hline \multirow{3}{*}{ Carr index (IC) (\%) } & 55 & $4.69 \mathrm{aA}$ & $4.62 \mathrm{aA}$ \\
\hline & 65 & $4.49 \mathrm{aA}$ & $4.77 \mathrm{aA}$ \\
\hline & 75 & $4.35 \mathrm{aA}$ & $4.55 \mathrm{aA}$ \\
\hline
\end{tabular}

Means followed by the same lowercase letter in the columns and upper case in the rows do not differ statistically by the Tukey test, at $5 \%$ probability.

It was observed that there is no defined tendency for water activity, due to the no significant differences in the moisture contents with the increase of drying temperature and the increase of air velocity. 
There was no direct relationship between the protein content and the drying conditions used, which also did not influence the lipid content. Similar behavior was reported by Oliveira et al. (2010) for white oat grains submitted to drying at different temperatures $\left(50,75\right.$ and $\left.100{ }^{\circ} \mathrm{C}\right)$, with no significant statistical changes in the lipid content found.

There was an increasing tendency for the starch content as the drying temperature increased, in which the values varied up to $21 \%$ between the lower and higher sets of temperature and air velocity. Higher values of starch were determined by Chisté et al. (2011) in flours elaborated with fermented roots (70.20 to $71.40 \%)$.

There was a decreasing tendency for the crude fiber content as the drying temperature increased. The variations observed in the color parameters do not allow to determine a tendency of variation with the temperature or the air velocity, coinciding only the lower value of luminosity in the lower temperature, for both air velocities.

As the drying temperature increased, there was a decrease in bulk density values, possibly reflecting a more irregular pattern on the surface of the particles. Close values were found by Falade and Christopher (2015) for bulk rice flour, with an bulk density that varied from 0.46 to $0.60 \mathrm{~g} / \mathrm{cm}^{3}$.

The tapped density also presented a decreasing tendency as observed for the bulk density, with the increase of the drying temperature, which corroborates with the influence of the temperature on the surface conformation and consequent volumetric accommodation of the particles. It was observed that as the temperature increased the particle density tended to decrease. This decrease may be associated with the fact that higher temperatures create pores and channels for toluene

The Hausner Factor was developed to evaluate the fluidity of materials by the ratio between the bulk and tapped density. Values smaller than 1.25 indicate good flow; greater than 1.5 indicate poor flow; values between 1.25 and 1.5 require the addition of adjuvants to improve flow. It was verified that there was no significant difference in HF between the averages of the flours, with results between 1.045 and 1.050, indicative of low cohesiveness, according to Quispe-Condori et al. (2011). The Carr Index, which also indicates powder and flour fluidity, was not influenced by increases in temperature or air velocity. All flours presented good fluidity since CI values between 15-20\% represent good fluidity, between 20-35\% poor fluidity, between $35-45 \%$ bad fluidity and CI > 45, very poor fluidity (Santhalakshmy et al. 2015).

Table 4 shows the values of solubility, water absorption capacity (WAC), oil absorption capacity (OAC), activity and emulsion stability of germinated jackfruit seed flour dried at three temperatures and two air velocities. 
Table 4. Mean values of the technological properties of germinated jackfruit seed flour obtained under different drying temperatures and air velocities

\begin{tabular}{|c|c|c|c|}
\hline & \multirow{2}{*}{$\begin{array}{c}\text { Temperature } \\
\left({ }^{\circ} \mathrm{C}\right)\end{array}$} & \multicolumn{2}{|c|}{ Air velocity $\left(\mathrm{m} \mathrm{s}^{-1}\right)$} \\
\hline & & 1.0 & 1.3 \\
\hline \multirow{3}{*}{ Solubility (\%) } & 55 & $19.76 \mathrm{aB}$ & $20.52 \mathrm{bA}$ \\
\hline & 65 & $19.95 \mathrm{aA}$ & $20.19 \mathrm{bA}$ \\
\hline & 75 & $20.01 \mathrm{aB}$ & $21.63 \mathrm{aA}$ \\
\hline \multirow{3}{*}{$\begin{array}{c}\text { CAA (g of water/100 } \\
\text { g of sample) }\end{array}$} & 55 & $205.25 \mathrm{aA}$ & $208.97 \mathrm{aA}$ \\
\hline & 65 & $222.48 \mathrm{aA}$ & $202.83 \mathrm{aB}$ \\
\hline & 75 & $207.49 \mathrm{aA}$ & $203.26 \mathrm{aA}$ \\
\hline \multirow{3}{*}{$\begin{array}{c}\text { CAO ( } \mathrm{g} \text { of oil/100 g } \\
\text { of sample) }\end{array}$} & 55 & $73.55 \mathrm{aA}$ & $74.62 \mathrm{aA}$ \\
\hline & 65 & $74.44 \mathrm{aA}$ & $74.85 \mathrm{aA}$ \\
\hline & 75 & $74.93 \mathrm{aA}$ & $74.90 \mathrm{aA}$ \\
\hline \multirow{3}{*}{$\begin{array}{l}\text { Emulsion activity } \\
\qquad(\%)\end{array}$} & 55 & $40.88 \mathrm{aA}$ & $40.10 \mathrm{aA}$ \\
\hline & 65 & $39.21 \mathrm{aA}$ & $39.68 \mathrm{aA}$ \\
\hline & 75 & $39.34 \mathrm{aA}$ & $38.35 \mathrm{aA}$ \\
\hline \multirow{3}{*}{$\begin{array}{l}\text { Emulsion stability } \\
\qquad(\%)\end{array}$} & 55 & $41.26 \mathrm{aA}$ & $40.11 \mathrm{aA}$ \\
\hline & 65 & $38.53 \mathrm{bB}$ & $40.74 \mathrm{aA}$ \\
\hline & 75 & $39.28 \mathrm{abA}$ & $36.61 \mathrm{bB}$ \\
\hline
\end{tabular}

The solubility of the flours varied in a small margin, statistically not significant in most cases. Elkhalifa and Bernhardt (2010) evaluated the solubility of the germinated sorghum grain flour and observed an increase in the 5th day of germination, from 42.32 to $63.20 \%$, which was attributed to the gradual degradation of reserve proteins in amino acids and peptides by increased levels of proteases. 


\section{Macrothink}

Journal of Agricultural Studies

ISSN 2166-0379

2020, Vol. 8, No. 1

In general, it was observed that there was no influence by the increase in temperature and air velocity on the water absorption capacity. Cheng and Bhat (2016) found a water absorption capacity of $82.28 \%$ in wheat flour while jering seed flour (Pithecellobium jiringa Jack) reached 288.25\%. According to Elkhalifa and Bernhardt (2010), the increase of the water absorption capacity in germinated seed flour compared to the in natura seeds can be attributed to an increase in the content and alteration in the quality of the protein caused by the germination.

No statistical difference was observed for oil absorption capacity, between the flours evaluated. Close values for oil absorption capacity were determined by Falade and Christopher (2015) in flours from six rice cultivars in Nigeria, with values varying from 59.97 to $72.98 \%$; higher values were found by Cheng and Bhat (2016) for wheat flour and jerry seed (Pithecellobium jiringa Jack), with oil absorption capacity of 147.39 and $163.02 \%$, respectively. These values indicate high potential for use in food products, particularly for bakery products and meat products, considering that the water and oil absorption capacity are parameters that affect texture, taste, and consistency.

It was observed that there was no significant difference between the emulsion activity of the flours, not affected, therefore, by the drying temperature and air velocity. Leite et al. (2016) reported that, after germination, there was an increase of emulsion activity (EA) of sorghum flour by about $5 \%$, but with a decrease in the emulsion stability (ES).

The results for emulsion stability (ES) did not show a well-defined tendency, although under the extreme conditions of $55^{\circ} \mathrm{C}$ and air velocity of $1.0 \mathrm{~m} \mathrm{~s}^{-1}$ and $75{ }^{\circ} \mathrm{C}$, and air velocity of 1,3 $\mathrm{m} \mathrm{s}^{-1}$ showed the highest and lowest values of emulsion stability, respectively.

\subsection{Moisture Adsorption Isotherms of Flours}

Table 5 shows the adjustment parameters of the Oswin, GAB and Peleg models adjusted to the moisture adsorption data at $25^{\circ} \mathrm{C}$, determined in the six flours produced under drying temperatures of 55,65 and $75{ }^{\circ} \mathrm{C}$ and air velocities of 1.0 and $1.3 \mathrm{~m} \mathrm{~s}^{-1}$, with respective determination coefficients $\left(\mathrm{R}^{2}\right)$ and the mean percentage deviations $(\mathrm{P})$. 
Table 5. Parameters of the Oswin, GAB and Peleg models adjusted to the data of moisture adsorption of germinated jackfruit flours, at $25^{\circ} \mathrm{C}$

\begin{tabular}{|c|c|c|c|c|c|c|c|}
\hline \multirow{2}{*}{ Models } & \multirow{2}{*}{$\begin{array}{c}\text { Temp. }\left({ }^{\circ} \mathbf{C}\right) / \\
\text { Air Veloc. }(\mathbf{m} \\
\left.\mathbf{s}^{-1}\right)\end{array}$} & \multicolumn{4}{|c|}{ Parameters } & \multirow{2}{*}{$\mathbf{R}^{2}$} & \multirow{2}{*}{$\begin{array}{c}P \\
(\%)\end{array}$} \\
\hline & & $\mathrm{a}$ & \multicolumn{3}{|c|}{$\mathrm{b}$} & & \\
\hline \multirow{6}{*}{ Oswin } & $55-1.0$ & 8.4952 & \multicolumn{3}{|c|}{0.5128} & 0.9962 & 2.28 \\
\hline & $55-1.3$ & 8.3293 & \multicolumn{3}{|c|}{0.5433} & 0.9969 & 2.56 \\
\hline & $65-1.0$ & 6.6516 & \multicolumn{3}{|c|}{0.5956} & 0.9972 & 3.06 \\
\hline & $65-1.3$ & 8.0478 & \multicolumn{3}{|c|}{0.6535} & 0.9934 & 3.55 \\
\hline & $75-1.0$ & 6.9259 & \multicolumn{3}{|c|}{0.6445} & 0.9965 & 3.36 \\
\hline & $75-1.3$ & 7.7498 & \multicolumn{3}{|c|}{0.5699} & 0.9993 & 0.90 \\
\hline \multirow{7}{*}{ GAB } & $\begin{array}{l}\text { Temp. }\left({ }^{\circ} \mathrm{C}\right) / \text { Air } \\
\text { Veloc. }\left(\mathrm{m} \mathrm{s}^{-1}\right)\end{array}$ & $X_{m}$ & \multicolumn{2}{|c|}{$\mathrm{C}$} & $\mathrm{K}$ & $\mathrm{R}^{2}$ & $\begin{array}{c}\mathrm{P} \\
(\%)\end{array}$ \\
\hline & $55-1.0$ & 4.6596 & \multicolumn{2}{|c|}{34.1737} & 0.9179 & 0.9929 & 2.98 \\
\hline & $55-1.3$ & 4.4647 & \multicolumn{2}{|c|}{158.1783} & 0.9342 & 0.9975 & 1.76 \\
\hline & $65-1.0$ & 4.2173 & \multicolumn{2}{|c|}{4.5625} & 0.9304 & 0.9981 & 2.63 \\
\hline & $65-1.3$ & 5.9182 & \multicolumn{2}{|c|}{2.2338} & 0.9324 & 0.9976 & 2.49 \\
\hline & $75-1.0$ & 4.6132 & \multicolumn{2}{|c|}{3.3921} & 0.9417 & 0.9969 & 2.67 \\
\hline & $75-1.3$ & 4.2020 & \multicolumn{2}{|c|}{34018.72} & 0.9414 & 0.9987 & 0.91 \\
\hline \multirow{7}{*}{ Peleg } & $\begin{array}{l}\text { Temp. }\left({ }^{\circ} \mathrm{C}\right) / \text { Air } \\
\text { Veloc. }\left(\mathrm{m} \mathrm{s}^{-1}\right)\end{array}$ & $\mathrm{k}_{1}$ & $\mathrm{n}_{1}$ & $\mathrm{k}_{2}$ & $\mathrm{n}_{2}$ & $\mathrm{R}^{2}$ & $\begin{array}{c}\mathrm{P} \\
(\%)\end{array}$ \\
\hline & $55-1.0$ & 35.0589 & 11.8710 & 18.6999 & 1.0883 & 0.9938 & 3.16 \\
\hline & $55-1.3$ & 15.8871 & 0.8389 & 39.0701 & 9.8725 & 0.9961 & 2.23 \\
\hline & $65-1.0$ & 17.5919 & 1.4318 & 34.5270 & 11.870 & 0.9991 & 1.55 \\
\hline & $65-1.3$ & 45.3412 & 8.9871 & 19.1243 & 1.3649 & 0.9965 & 2.65 \\
\hline & $75-1.0$ & 44.5359 & 13.6700 & 21.9112 & 1.7372 & 0.9974 & 2.16 \\
\hline & $75-1.3$ & 40.4980 & 12.6263 & 19.5598 & 1.3360 & 0.9983 & 1.39 \\
\hline
\end{tabular}


It was verified that all the models had good adjustments to the experimental data, with values of $\mathrm{R}^{2}>0.96$ and $\mathrm{P}<10 \%$, the Oswin, GAB and Peleg models, presented the best adjustments with $\mathrm{R}^{2}>0.99$ and $\mathrm{P}<3 \%$. Kartika et al. (2012) when evaluated the moisture adsorption isotherms of Pinhão Bravo seeds verified good adjustments by the GAB and Oswin models to the experimental data.

Oscillations are observed in the moisture content values in the molecular monolayer $(\mathrm{Xm})$ of the GAB model with no demonstration of the effects of temperature and air velocity. Xm is a critical parameter since it represents the moisture content in which the rate of any associated reaction will be negligible due to the strong binding of water to the surface (Yogendrarajah et al., 2015). The molecular monolayer is the primary food layer and its moisture content interferes with the hygroscopicity or affinity of the molecules with water (Ribeiro et al., 2016).

The values of the $\mathrm{C}$ parameter of the GAB model, which is related to the adsorption heat of the water on the product (Velázquez-Gutiérrez et al., 2015), also did not follow a tendency with temperature or air velocity. According to Velázquez-Gutiérrez et al. (2015), lower values of $\mathrm{C}$ occur the greater interactions between the product and the water vapor. The constant $\mathrm{K}$ of the GAB model, which represents the water adsorption capacity in the multilayers (Abebe et al., 2015), showed an increasing tendency with temperature but did not demonstrated influence of air velocity.

The parameters found for the Oswin model $a>0$ and $0<\mathrm{b} \leq 1$, this indicates that the curves have no inflection point and concavity changes. According to Rocha et al. (2014) these parameters are physically and mathematically consistent. From the $\mathrm{C}$ and $\mathrm{K}$ values of the GAB model, the moisture adsorption isotherms for the germinated jackfruit seed flours are Type II (sigmoid form), according to Blahovec's classification (2004), considered that they presented $0<\mathrm{K} \leq 1$ and $\mathrm{C}>2$, except for the dry flour at $65{ }^{\circ} \mathrm{C}$ and velocity of $1.3 \mathrm{~m} \mathrm{~s}^{-1}$, which presented $0<\mathrm{K} \leq 1$ and $0 \leq \mathrm{C} \leq 2$, classified as Type III (type J). The predominance of the first type reflects the higher proportion of carbohydrates, according to Chiste et al. (2011), where they affirmed that the number of sites that bind strongly to water molecules should be lower on the protein-rich substrate than on the carbohydrate-rich substrate, so that starch products generally have Type II isotherms.

In Figures 1 and 2 are presented the moisture adsorption isotherms of the flours at $25{ }^{\circ} \mathrm{C}$, with adjustments by the GAB model. According to Yogendrarajah et al. (2015), the safe moisture content for storage is $\mathrm{a}_{\mathrm{w}} \leq 0.60$, which in the germinated jackfruit flours corresponds to moisture contents of less than $12 \%$ (b.s). 


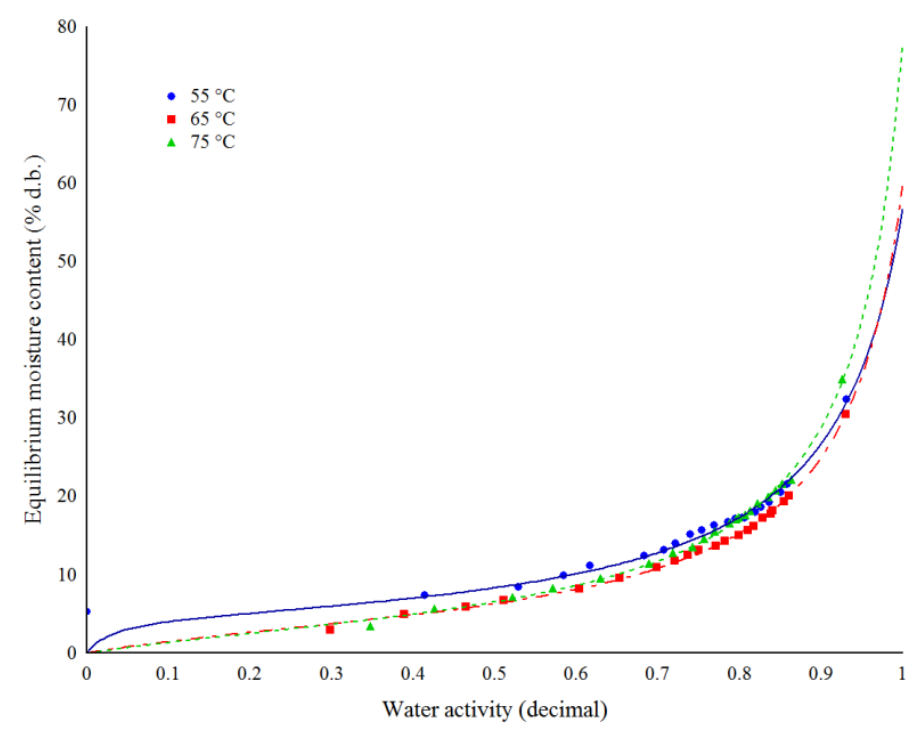

Figure 1. Moisture adsorption isotherms of germinated jackfruit flour at $25{ }^{\circ} \mathrm{C}$ adjusted by the $\mathrm{GAB}$ model for the different drying temperatures and air velocity of $1.0 \mathrm{~m} \mathrm{~s}^{-1}$

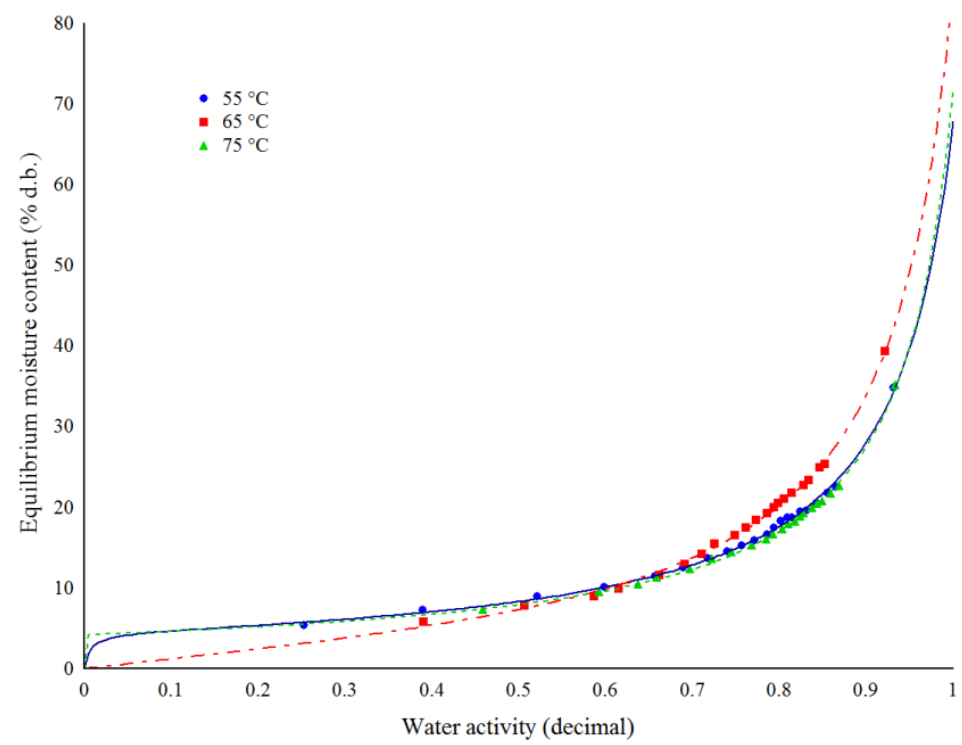

Figure 2. Moisture adsorption isotherms of germinated jackfruit flour at $25{ }^{\circ} \mathrm{C}$ adjusted by the GAB model for the different drying temperatures and air velocity of $1.3 \mathrm{~m} \mathrm{~s}^{-1}$

The equilibrium moisture content of the flours ranged from 2,9454 to $39,38 \%$ (d.b.) for aw between 0.298 and 0.922 , this range is close tow what is found for the biodegradable starch films of jackfruit and glycerol, with a range between 2,242 and 22,192\% (d.b.) for aw between 0.113 and 0.836 (Barbosa et al., 2011). From the isotherms, there is no evident relation of the hygroscopic behavior of the flours with the temperature or the air-drying velocity of the seeds.

\subsection{Flour Particles Morphology}

The flour of the germinated jackfruit seeds was submitted to X-ray diffraction analysis 


\section{Macrothink}

(Figure 3), presented three peaks between 15 and 25 diffraction angles, with a quality standard of type A. According to Lima et al. (2012), the X-ray diffraction technique allows to distinguish three types of crystallinity of the starch granules that, according to Zobel (1964), depending on their crystalline form and structure, are called type A, B and C. Lima et al. (2012) found in corn starch and wheat flakes x-ray diffractograms with $2 \mathrm{q}$ peaks related to the type A crystallinity pattern, whereas potato starch flour and banana flour showed characteristic peaks of type B crystallinity. Pattern A is characteristic of cereals, the B pattern is characteristic of tubers, fruits, high amylose corn, and retrograded starches. The C Pattern is considered a mixture of $\mathrm{A}$ and $\mathrm{B}$ patterns and is characteristic of legume starches (Bello-Perez et al., 2006).

In Figure 4 is presented the scanning electron microscope (SEM) photomicrograph of the jackfruit germinated seed flour at 500x magnification. Morphologically rounded structures with varying sizes and smooth surfaces were observed. According to Xue et al. (2017), the main component of the flour is starch, thus the polygonal or irregularly shaped granules observed in the microphotographs are starch granules. According to Otegbayo et al. (2013), the variation in shape (polyhedral, oval and rounded) and size of the starch granules, is due to the drying treatment used and can be influenced by the amount of amylose and amylopectin.

Similar behavior was observed by Ma and Boye (2018) with lentil seed (Lens culinaris) and by Zhang et al. (2014) for lotus seed (Nelumbo nucifera). The existence of irregular structures with pores, depressions, and cracks in the microstructure of the sample may affect its stability during storage (Laokuldilok and Kanha, 2015).

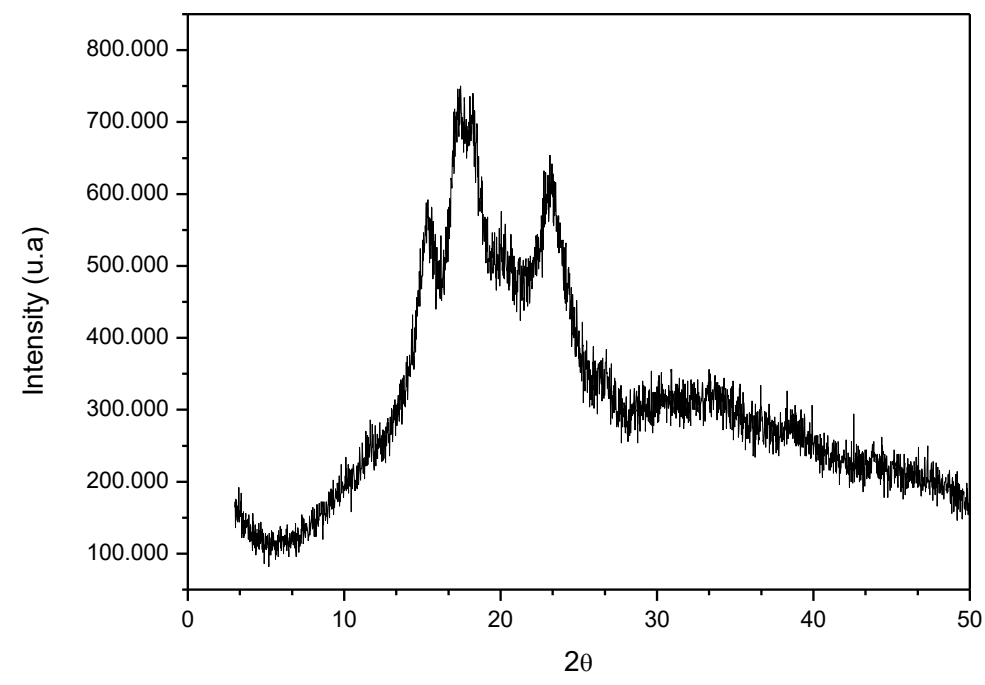

Figure 3. X-ray diffraction of the germinated seed flour $\left(75^{\circ} \mathrm{C}, 1.3 \mathrm{~m} \mathrm{~s}^{-1}\right)$ 


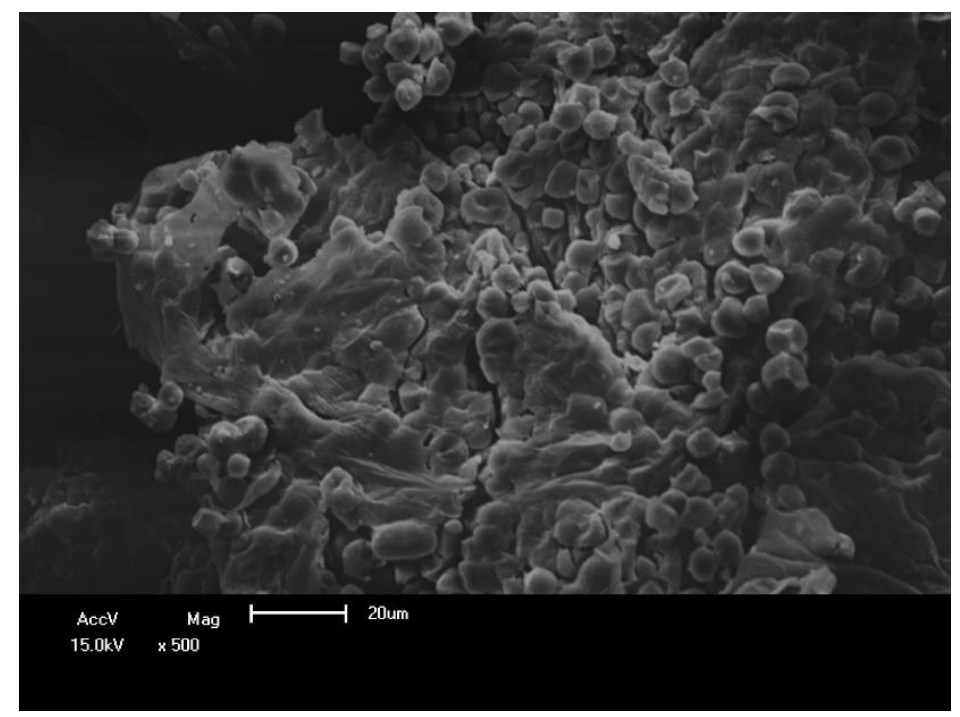

Figure 4. Scanning electron microscope (SEM) photomicrography of the germinated jackfruit seed flour $\left(75^{\circ} \mathrm{C}, 1.3 \mathrm{~m} \mathrm{~s}^{-1}\right)$ at $500 \times$ magnification

\section{Conclusion}

Germination increased moisture content, titratable total acidity, protein content, total sugars, water activity, luminosity, and fiber content; reduced the ash content, $\mathrm{pH}$, lipids, ascorbic acid, total carbohydrates, reducing sugars, tannins, phenolic compounds, specific mass and redness $\left(+\mathrm{a}^{*}\right)$ and yellowness $\left(+\mathrm{b}^{*}\right)$ intensities. The prospected minerals, potassium, phosphorus, magnesium, sulfur, zinc and copper also decreased with the germination process.

The germinated jackfruit seed flour had lower redness $\left(+\mathrm{a}^{*}\right)$ and higher luminosity $\left(\mathrm{L}^{*}\right)$. It showed good results for solubility, water absorption capacity, oil absorption capacity, and emulsifying properties .No well-defined influences of temperature and drying air velocity were detected on the chemical, physical and technological characteristics of the flour.

The moisture adsorption isotherms of the germinated jackfruit seed flour were classified as Type II. The GAB model was the one that best fit the experimental data, followed by the Peleg and Oswin models.

\section{Acknowledgment}

The authors would like to thank CNPq (National Council for Scientific and Technological Development) for the support given to this research.

\section{References}

Abebe, W., \& Ronda, F. (2015). Flowability, moisture sorption and thermal properties of tef [Eragrostis tef (Zucc.) Trotter] grain flours. Journal of Cereal Science, 63, 14-20. https://doi.org/10.1016/j.jcs.2015.02.003

Association of Official Analytical Chemistry (2009). Official methods of analysis of the Association of Official Analytical Chemistry. Washington: AOAC, 1115p.

Baliga, M. S., Scivashankara, R., Haniadka, R., \& Dsouza, J. (2011). Phytochemistry 
nutritional and pharmacological properties of Artocarpus heterophyllus Lam. (jackfruit): a review. Food Research International, 44(7), 1800-1811. https://doi.org/10.1016/j.foodres.2011.02.035

Barbosa, H. R., Ascheri, D. P. R., Ascheri, J. L. R., \& Carvalho, C. W. P. (2011). Permeability, stability and functionality of biodegradable starch films from jackfruit starch (Artocarpus $\begin{array}{lllll}\text { heterophyllus } \quad \text { Lam). } & \text { Revista } & \text { Agrotecnologia, } & \text { 2, }\end{array}$ https://doi.org/10.12971/2179-5959.v02n01a06

Bello-Pérez, L. A., Montealvo, M. G. M., \& Acevedo, E. A. (2006). Almidón: definicion, estructura y propiedades. In: LAJOLO, F.M.; MENEZES, E. W. Carbohidratos em alimentos regionales iberoamericano. São Paulo: Edusp (Chapter 1).

Beuchat, L. R. (1997). Functional and electrophoretic characteristic of succinylated peanut flour protein. Journal of Agricultural and Food Chemistry, 25(2), 258-260. https://doi.org/10.1021/jf60210a044

Bhusari, S. N., Muzaffar, K., \& Kumar, P. (2014). Effect of carrier agents on physical and microstructural properties of spray dried tamarind pulp powder. Powder Technology, 266, 354-364. https://doi.org/10.1016/j.powtec.2014.06.038

Blahovec, J. (2004). Sorption isotherms in materials of biological origin mathematical and physical approach. Journal of Food Engineering, 65(4), 489-495. https://doi.org/10.1016/j.jfoodeng.2004.02.012

Bligh, E. G., \& Dyer, W. J. (1959). A rapid method of total lipid extraction and purification. Canadian Journal Biochemistry Physiology, 37(8), 911-917. https://doi.org/10.1139/o59-099

Cano-Chauca, M., Stringheta, P. C., Ramos, A. M., \& Cal-Vidal, C. (2005). Effect of the carriers on the microstructure of mango power obtained by spray drying and its functional characterization. Innovative Food Science and Emerging Technologies, 6(4), 420-428. https://doi.org/10.1016/j.ifset.2005.05.003

Charoenthaikij, P., Jangchud, K., Jangchud, A., Prinyawiwatkul, W., \& No, H. K. (2012). Composite wheat-germinated brown rice flours: selected physicochemical properties and bread application. International Journal of Food Science \& Technology, 47(1), 75-82. https://doi.org/10.1111/j.1365-2621.2011.02809.x

Cheng, Y. F., \& Bhat, R. (2016). Functional, physicochemical and sensory properties of novel cookies produced by utilizing underutilized jering (Pithecellobium jiringa Jack.) legume flour. Food Bioscience, 14, 54-61. https://doi.org/10.1016/j.fbio.2016.03.002

Chisté, R. C., \& Cohen, K. O. (2011). Influence of fermentation on the quality of the cassava flour of the water group. Acta Amazonica, 41(2), 279-284. http://dx.doi.org/10.1590/S0044-59672011000200013

Cornejo, F., Caceres, P. J., Martínez-Villaluenga, C., Rosell, C. M., \& Frias, J. (2015). Effects of germination on the nutritive value and bioactive compounds of brown rice breads. Food Chemistry, 173, 298-304. https://doi.org/10.1016/j.foodchem.2014.10.037 
Crapiste, G. H., \& Rotstein, E. (1982). Prediction of sorption equilibrium data for starch-containing food stuffs. Journal of Food Science, 47(5), 1501-1507. https://doi.org/10.1111/j.1365-2621.1982.tb04970.x

Devilla, I. A., Neto, M. C. O., \& Reis, R. C. (2010). Physical properties of bean (Phaseolus vulgaris L.) seeds variety "Emgopa 201 - Gold". Revista Agrotecnologia, 1, 99-109. http://dx.doi.org/10.12971/2179-5959.v01n01a07

Eastman, J. E., \& Moore, C. O. (1984). Cold water-soluble granular starch for gelled food composition. U. S. Patent 4465702.

Elkhalifa, A. E. O., \& Bernhardt, R. (2010). Influence of grain germination on functional properties of sorghum flour. Food Chemistry, 121(2), 387-392. https://doi.org/10.1016/j.foodchem.2009.12.041

Falade, K. O., \& Christopher, A. S. (2015). Physical, functional, pasting and thermal properties of flours and starches of six Nigerian rice cultivars. Food Hydrocolloids, 44, 478-490. https://doi.org/10.1016/j.foodhyd.2014.10.005

Goldstein, J. L., \& Swain, T. (1963). Changes in tannis in ripening fruits. Phytochemistry, 2(4), 371-383. https://doi.org/10.1016/S0031-9422(00)84860-8

Huang, X., Cai, W., \& Xu, B. (2014). Kinetic changes of nutrients and antioxidant capacities of germinated soybean (Glycine max L.) and mung bean (Vigna radiata L.) with germination time. Food Chemistry, 143, 268-276. https://doi.org/10.1016/j.foodchem.2013.07.080

Instituto Adolfo Lutz (São Paulo). Physicochemical methods for food analysis. São Paulo: Instituto Adolfo Lutz, 2008. 1020p.

Kartika, A., Yuliane, S., Kailaku, S. I., \& Rigal, L. (2012). Moisture sorption behaviour of jatropha seed (Jatropha curcas) as a source of vegetable oil for biodiesel production. Biomass and Bioenergy, 36, 226-233. https://doi.org/10.1016/j.biombioe.2011.10.026

Laokuldilok, T., \& Kanha, N. (2015). Effects of processing conditions on powder properties of black glutinous rice (Oryza sativa L.) bran anthocyanins produced by spray drying and freeze drying. LWT-Food Science and Technology, 64(1), 405-411. https://doi.org/10.1016/j.lwt.2015.05.015

Leite, D. D. F., Cavalcanti, M. T., Silva, A. S., Gonçalves, M. C., \& Almeida, M. C. B. M. (2016). Functional properties of sorghum seed (Sorghum bicolor (L.) Moench) in natura and germinated. Revista Verde de Agroecologia e Desenvolvimento Sustentável, 11(1), 07-11. https://doi.org/10.18378/rvads.v11i1.4076

Lima, B. N. B., Cabral, T. B., Neto, R. P. C., \& Tavares, M. I. B. (2012). Estudo do amido de farinhas comerciais comestíveis. Polímeros [online], 22(5), 486-490. https://doi.org/10.1590/S0104-14282012005000062

Ma, Z., \& Boye, J. I. (2018). Research advances on structural characterization of resistant starch and its structure-physiological function relationship: A review. Critical Reviews in 
Food Science \& Nutrition, 58(7), 1059-1083.

https://doi.org/10.1080/10408398.2016.1230537

Madrigal-Aldana, D. L., Tovar-Gomez, B., Oca, M. M., Sayago-Ayerdi, S. G., Gutierrez-Meraz, F., \& Bello-Perez, L. A. (2011). Isolation and characterization of Mexican jackfruit (Artocarpus heterophyllus L.) seeds starch in two mature stages. Starch, 63(6), 364-372. https://doi.org/10.1002/star.201100008

Madruga, M., Samara, M. A. F., Rafaela, A. S. I., Silva, A. D., Magnani, M., \& Queiroga Neto, V. (2014). Chemical, morphological and functional properties of Brazilian jackfruit (Artocarpus heterophyllus Lam) seeds starch. Food Chemistry, 143, 440-445. https://doi.org/10.1016/j.foodchem.2013.08.003

Martinez, A. P. C., Martinez, P. C. C., Souza, M. C., \& Canniatti-Brazaca, S. G. (2011). Alterações químicas em grãos de soja com a germinação. Ciência e Tecnologia de Alimentos, 31(1), 23-30. http://dx.doi.org/10.1590/S0101-20612011000100004

Miller, G. L. (1959). Use of dinitrosalicylic acid reagent for determination of reducing sugar. Analytical Chemistry, 31(3), 426 - 428. https://doi.org/10.1021/ac60147a030

Naves, L. P., Corrêa, A. D., Abreu, C. M. P., \& Santos, C. D. (2010). Nutrientes e propriedades funcionais em sementes de abóbora (Cucurbita maxima) submetidas a diferentes processamentos. Ciência e Tecnologia de Alimentos, 30(1), 190-195. http://dx.doi.org/10.1590/S0101-20612010000500028

Oliveira, L. C., Gutkoski, L. C., Elias, M. C., Mazzutti, S., Aosani, E., \& Rocha, J. C. (2010). Efeito da temperatura de secagem na qualidade de grãos de aveia branca. Ciência $e$ Agrotecnologia, 34(2), 313-319. http://dx.doi.org/10.1590/S1413-70542010000200007

Otegbayo, B., Oguniyan, D., \& Akinwumi, O. (2013). Physicochemical and functional characterization of yam starch for potential industrial applications. Starch, 66(3), 235-250. https://doi.org/10.1002/star.201300056

Quispe-Condori, S., Saldaña, M. D. A., \& Temelli, F. (2011). Microencapsulation of flax oil with zein using spray and freeze-drying. LWT - Food Science and Technology, 44(9), 1880-1887. http://dx.doi.org/10.1016/j.lwt.2011.01.005

Ribeiro, L. C., Costa, J. M. C., \& Afonso, M. R. A. (2016). Hygroscopic behavior of lyophilized acerola pulp powder. Revista Brasileira de Engenharia Agrícola e Ambiental, 20(3), 269-274. http://dx.doi.org/10.1590/1807-1929/agriambi.v20n3p269-274

Rocha, E. M. F. F., Rodrigues, S., Afonso, M. R. A., \& Costa, J. M. C. (2014). Mathematical modeling for isotherms of mango pulp powder, obtained by atomization. Journal of Encapsulation and Adsorption Sciences, 4(1), 8-14.

http://dx.doi.org/10.4236/jeas.2014.41002

Santhalakshmy, S., Bosco, S. J. D., Francis, S., \& Sabeena, M. (2015). Effect of inlet temperature on physicochemical properties of spray-dried jamun fruit juice powder. Powder Technology, 274, 37-43. https://doi.org/10.1016/j.powtec.2015.01.016 
Silva, F. A. S., \& Azevedo, C. A. V. (2016). The Assistat Software Version 7.7 and its use in the analysis of experimental data. African Journal of Agricultural Research, 11(39), 3733-3740. https://doi.org/10.5897/AJAR2016.11522

Silva, T. T. A., Souza, L. A., Oliveira, L. M., \& Mendes, R. G. (2007). Temperature of germination, sensitivity to desiccation and storage of jackfruit seeds. Revista Ciência Agronômica, 38(4), 436-439.

Souza, G. B., Nogueira, A. R. A., Sumi, L. N., \& Batista, L. A. R. (1999). Alternative method for determination of neutral detergent fiber and acid detergent. São Carlos: Embrapa Pecuária Sudoeste. 21p.

Stevens, F. J., \& Chapman, R. A. (1955). The determination of starch in meat products with the anthrone reagent. Journal of Association of Official Analytical Chemists, 38, 202-210.

Tian, B., Xie, B., Shi, J., Wu, J., Cai, Y., Xu, T., ... Deng, Q. (2010). Physicochemical changes of oat seeds during germination. Food Chemistry, 119(3), 1195-1200. https://doi.org/10.1016/j.foodchem.2009.08.035

Tonon, R. V., Brabet, C., \& Hubinger, M. D. (2013). Aplicação da secagem por atomização para a obtenção de produtos funcionais com alto valor agregado a partir do açaí. Inclusão Social, 6(2), 70-76.

Velázquez-Gutiérrez, S. K., Figueira, A. C., Rodríguez-Huezo, M. E., Román-Guerrero, A., Carrillo-Navas, H., \& Pérez-Alonso, C. (2015). Sorption isotherms, thermodynamic properties and glass transition temperature of mucilage extracted from chia seeds (Salvia hispanica L.). Carbohydrate Polymers, 121, 411-419.

https://doi.org/10.1016/j.carbpol.2014.11.068

Waterhouse, A. (2006). Folin-ciocalteau micro method for total phenol in wine. American Journal of Enology and Viticulture, p. 3-5.

Xue, P., Zhao, Y., Wen, C., Cheng, S., \& Lin, S. (2017). Effects of electron beam irradiation on physicochemical properties of corn flour and improvement of the gelatinization inhibition. Food Chemistry, 233, 467-47. https://doi.org/10.1016/j.foodchem.2017.04.152

Yasumatsu, K., Sawada, K., Moritaka, S., Misaki, M., Toda, J., \& Wada, T. (1972). Whipping and emulsifying properties of soybean products. Agricultural and Biological Chemistry, 36(5), 719-725. https://doi.org/10.1080/00021369.1972.10860321

Yemm, E. W., \& Willis, A. J. (1954). The estimation of carbohydrates in plant extracts by anthrone. Biochemical Journal, 57(3), 508-515. https://dx.doi.org/10.1042\%2Fbj0570508

Yogendrarajah, P., Samapundo, S., Devlieghere, F., Saeger, S., \& Meulenaer, B. (2015). Moisture sorption isotherms and thermodynamic properties of whole black peppercorns (Piper nigrum L.). LWT-Food Science and Technology, 64(1), 177-188. https://doi.org/10.1016/j.lwt.2015.05.045

Zhang, Y., Zeng, H., Wang, Y., Zeng, S., \& Zheng, B. (2014). Structural characteristics and 


\section{Macrothink}

Journal of Agricultural Studies

ISSN 2166-0379 2020, Vol. 8, No. 1

crystalline properties of lotus seed resistant starch and its prebiotic effects. Food Chemistry, 155, 311-318. https://doi.org/10.1016/j.foodchem.2014.01.036

Zobel, H. F. (1964). X-ray analysis of starch granules. In: WHISTLER, R. L.; SMITH, R. J.; BEMILLER, J. N. (eds.) Methods in Carbohydrate Chemistry. New York: Academic Press, p. 109-113.

\section{Copyright Disclaimer}

Copyright for this article is retained by the author(s), with first publication rights granted to the journal.

This is an open-access article distributed under the terms and conditions of the Creative Commons Attribution license (http://creativecommons.org/licenses/by/4.0/). 